\title{
"The methodological approaches development to assess the creation and use of the financial capacity of the state"
}

\begin{tabular}{|c|c|}
\hline \multirow{5}{*}{ AUTHORS } & Nataliya Vyhovska iD https://orcid.org/0000-0001-7129-6169 \\
\hline & R http://www.researcherid.com/rid/B-2434-2018 \\
\hline & Andrii Polchanov (D) https://orcid.org/0000-0001-6019-9275 \\
\hline & \multirow{2}{*}{$\begin{array}{l}\text { Khaled Aldiwani } \\
\text { Fathi Shukairi iD https://orcid.org/0000-0003-0381-4707 }\end{array}$} \\
\hline & \\
\hline ARTICLE INFO & $\begin{array}{l}\text { Nataliya Vyhovska, Andrii Polchanov, Khaled Aldiwani and Fathi Shukairi } \\
\text { (2019). The methodological approaches development to assess the creation and } \\
\text { use of the financial capacity of the state. Public and Municipal Finance, 8(1), 28- } \\
\text { 43. doi:10.21511/pmf.08(1).2019.03 }\end{array}$ \\
\hline DOI & http://dx.doi.org/10.21511/pmf.08(1).2019.03 \\
\hline RELEASED ON & Tuesday, 07 May 2019 \\
\hline RECEIVED ON & Saturday, 23 March 2019 \\
\hline ACCEPTED ON & Tuesday, 16 April 2019 \\
\hline & $(\mathrm{cc}) \mathrm{EYY}_{\mathrm{E}}$ \\
\hline LICENSE & $\begin{array}{l}\text { This work is licensed under a Creative Commons Attribution } 4.0 \text { International } \\
\text { License }\end{array}$ \\
\hline JOURNAL & "Public and Municipal Finance" \\
\hline ISSN PRINT & $2222-1867$ \\
\hline ISSN ONLINE & $2222-1875$ \\
\hline PUBLISHER & LLC "Consulting Publishing Company "Business Perspectives" \\
\hline FOUNDER & LLC "Consulting Publishing Company "Business Perspectives" \\
\hline & 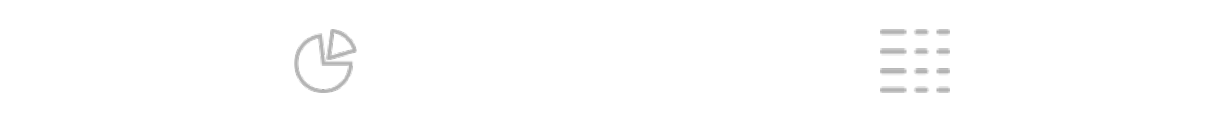 \\
\hline NUMBER OF REFERENCES & NUMBER OF FIGURES \\
\hline 23 & 8 \\
\hline
\end{tabular}

(C) The author(s) 2021. This publication is an open access article. 


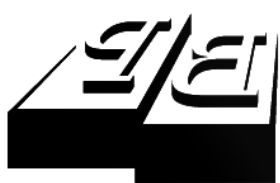

BUSINESS PERSPECTIVES

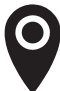

LLC "CPC "Business Perspectives" Hryhorii Skovoroda lane, 10, Sumy, 40022, Ukraine

www.businessperspectives.org

Received on: $23^{\text {rd }}$ of March, 2019 Accepted on: $16^{\text {th }}$ of April, 2019
(C) Limited Liability Company

"Consulting Publishing Company

"Business Perspectives", 2019

Nataliya Vyhovska, Doctor of Economics, Professor, Zhytomyr State Technological University, Ukraine.

Andrii Polchanov, Ph.D., Associate Professor, Zhytomyr State Technological University, Ukraine.

Khaled Aldiwani, Ph.D. Student, University of Customs and Finance, Ukraine; Higher Institute of Science and Technology, Libyan Arab Jamahiriya.

Fathi Shukairi, Ph.D. Student University of Customs and Finance, Ukraine; National Oil Corporation, Libyan Arab Jamahiriya.
Nataliya Vyhovska (Ukraine), Andrii Polchanov (Ukraine),

Khaled Aldiwani (Libya), Fathi Shukairi (Libya)

THE METHODOLOGICAL APPROACHES DEVELOPMENT TO ASSESS THE CREATION AND USE OF THE FINANCIAL CAPACITY OF THE STATE

\begin{abstract}
The article focuses on the development of scientific and methodological approach to determining the level of creation and use of financial capacity to identify current trends of its transformation and perspective directions for development. The research urgency is due to the need to ensure high level of national security, ineffective use of the existing financial capacity of the state, disputability of scientific approaches to identifying its components and the need to choose the vector for the state's further development. This requires additional research methodological aspects aimed at obtaining objective and well-founded assessment of the financial capacity level.
\end{abstract}

The methodological approach proposed involves comparing the actual rated values of creation and use of the authorities' financial resources (the ratio of the deficit/surplus of the state budget to GDP, the level of GDP redistribution through the consolidated budget, the ratio of the government and government-guaranteed debt to GDP and gross international reserves of Ukraine in the months of imports), financial resources of business entities (the level of listing companies capitalization, the ratio of non-performing loans to total gross loans, credit interest rate, companies' ROA) and the financial resources of households (the share of cash income in total household resources, the ratio of the average amount of old-age pension to the average monthly nominal wage, the share of spending on food and non-alcoholic beverages in total household spending) with their recommended limits and the establishing a scoring making it possible to form an integral indicator that reflects the level of creation and use of the state's financial capacity. The methodological approach has been tested using Ukraine as an example. This has made it possible to identify the negative tendencies of the creation and use of Ukraine's financial capacity (the state budget imbalance, significant debt burden on the budget, high interest rates, significant share of household expenditure on consumption). Based on the results, perspectives for development of the state's financial capacity are proposed.

\section{Keywords}

\section{JEL Classification} development, debt, budget

O11, O12, H63, H61

\section{INTRODUCTION}

The financial capacity of the state cannot be developed without assessing its current situation and evaluating the results in order to increase its efficient use. The increase in importance of financial relations in the social reproduction processes and ensuring national security, inefficient use of the established financial capacity of the state, ambiguity of approaches to the identification of its components and the need to choose the priority directions of further development determine the relevance of analyzing methodological aspects aimed at obtaining objective and well-argued assessment of the financial capacity level. 


\section{LITERATURE REVIEW}

A number of scientists researched the issue of assessing the financial capacity of the state (both at the level of well-formed aggregate potential and at the level of its individual components, namely regions, enterprises and industries). In this context, Boronos (2012), Volkovskyi (2015), Indus (2016), Kostyrko (2015), Nazarova (2016), Portna (2015), Trusova (2016), Shumska (2007) and many other Ukrainian scientists should be mentioned. Adilova, Akayev, Zhatkanbayeva, and Zhumanova (2015), DexuHe (2016), Khalitova, Panzabekova, and Nurymova (2017), Redo and Siemiątkowski (2017), and Semjonova (2016) assessed the financial capacity of the state based on ensuring its financial security. At the same time, the only methodological approach to assessing the financial capacity of the state is not formed, which makes it difficult to formulate applied guidelines for improving the management of its components.

\section{AIM}

The aim of the research is to develop a scientific and methodological approach to determining the level of creation and use of the state's financial capacity using an integral indicator to identify current trends in its transformation and perspectives for its development.

\section{METHODS}

The following methods were used while writing the article: analysis (to divide the system of the state's financial capacity into separate elements with their further research); abstraction (to select relevant indicators for assessing the components of the state's financial capacity); comparison (to compare the actual financial capacity of Ukraine with the EU countries' financial capacity, as well as with the reference level of financial capacity, whose indicators of the efficient creation and use correspond to optimal values); statistical and economic methods (to study the changes in the indicators of financial capacity in the past and to identify relevant trends); synthesis (to identify the level of financial capacity of the state based on its elemental composition).

\section{RESULTS}

Based on the analysis of scientific publications on the creation and use of the state's financial capacity, significant diversity of opinions on the definition of its economic essence has been identified. This complicates the development of a methodological approach to its evaluation. Applying a systematic approach is very useful in the course of the state's financial capacity analysis (Indus, 2016; Kucher, 2014; Trusova, 2016, and others). This makes it possible to take into account internal connections between the financial capacity components and its susceptibility to the external factors.

According to Polchanov (2018), the subjects of the state's financial capacity are the basic element of the financial capacity system. Based on this, by the financial capacity of the state one understands the complex of financial resources of the authorities, business entities, households, as well as opportunities for their effective creation, distribution and use. The structure of the state's financial capacity is presented in Figure 1.

According to the authors, to assess the efficient creation and use of financial capacity comprehensively, it is expedient to use indicators presented in Table 1. This is due to their widespread usage by Ukrainian scholars, as well as due to consolidation of these indicators and the scale of their identification in the Methodological Recommendations for Assessing the Level of Economic Security, approved by the Order of the Ministry of Economic Development and Trade of Ukraine No. 1277 dated October 29, 2013 (Kucher, 2014).

According to Table 1, for most indicators, the recommended values are set so that they do not exceed their optimal values provided for by the Recommendations above. In addition, in the group of indicators for estimating the financial capacity of households, it is proposed to use the ratio of the average amount of the old-age pension to the average monthly nominal wage. In this case, the recommended value was established based on the optimal values of the ratio of the average monthly nominal wage to the subsistence rate per one able-bodied person and the ratio of the average old-age pension to the 
Source: Developed by the authors.

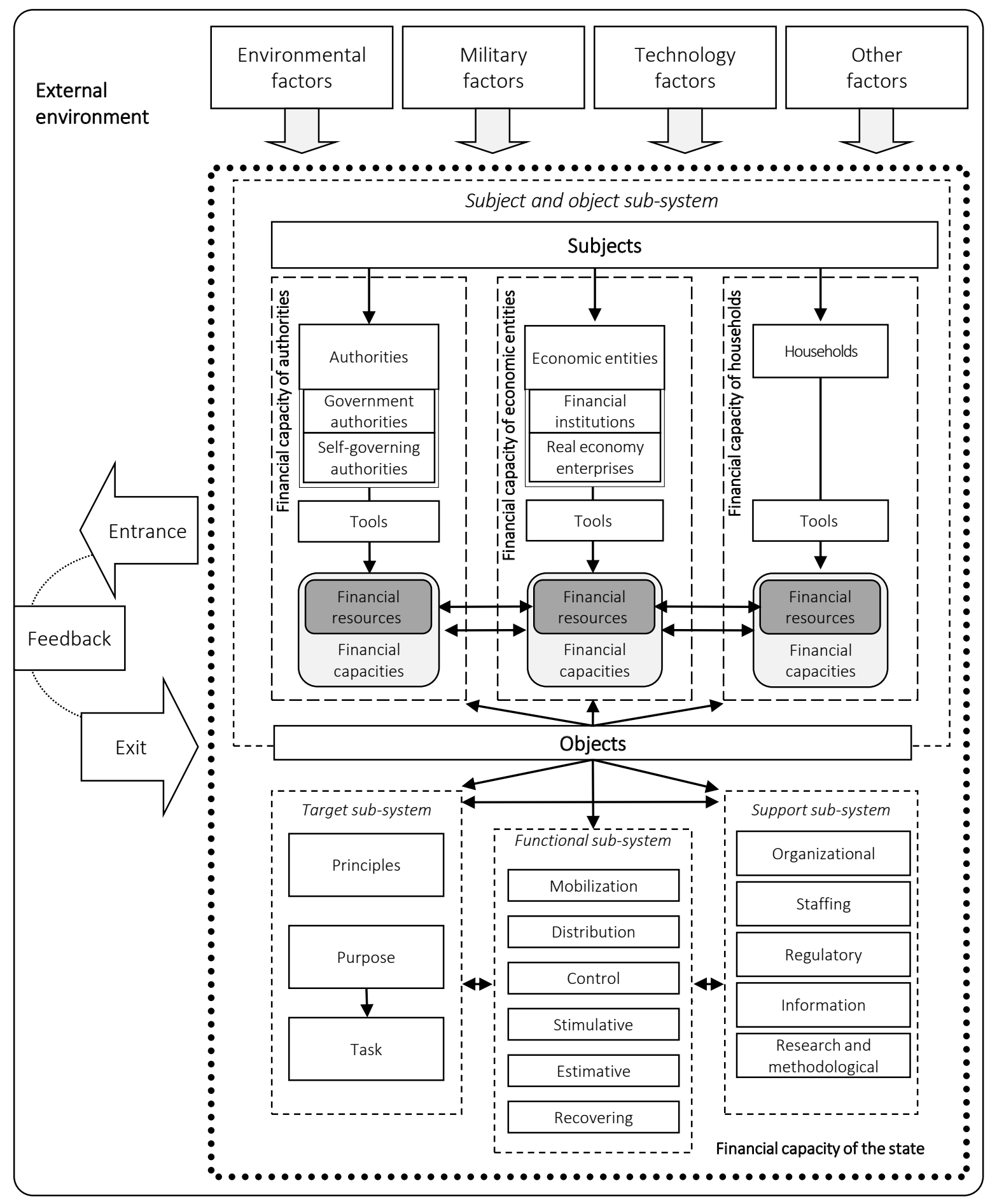

Figure 1. The state's financial capacity as a system

subsistence rate of people who lost their ability to work (Kucher, 2014). Given the importance of income for creating the financial capacity of households, the recommended value of the share of cash incomes in the total household resources was set at $100 \%$.
The individual recommended values of the financial capacity assessment indicators depend on the average for the EU countries, which makes it possible to take into account the pan-European trends in the key macro-financial indicators. In addition, it is proposed to evaluate dynamics of the indicated fac- 
Table 1. Recommended values of indicators of the efficient creation and use of the state's financial capacity

Source: Developed by the authors.

\begin{tabular}{|c|c|c|c|}
\hline No. & Indicator & $\begin{array}{l}\text { Type of an } \\
\text { indicator }\end{array}$ & Recommended value \\
\hline \multicolumn{4}{|c|}{ Financial capacity of authorities } \\
\hline 1 & Ratio of deficit/surplus of the state budget to GDP, percent & Mixed & $\begin{array}{c}\left(\max \left\{\tilde{O}_{E U} ;-6\right\} ; 10\right), \\
\text { where } x_{E U} \text { is the mean value in the } \\
\text { EU countries }\end{array}$ \\
\hline 2 & $\begin{array}{l}\text { Level of GDP redistribution through the consolidated budget, } \\
\text { percent }\end{array}$ & Mixed & $(18 ; 37)^{*}$ \\
\hline 3 & $\begin{array}{l}\text { Ratio of the amount of government and government-guaranteed } \\
\text { debt to GDP, percent }\end{array}$ & Disincentive & $\begin{array}{l}{\left[0 ; \min \left\{\tilde{O}_{E U} ; 60\right\}\right),} \\
\text { where } x_{E U} \text { is the mean value in the } \\
\text { EU countries }\end{array}$ \\
\hline 4 & Gross international reserves of Ukraine, months of imports & Incentive & $\begin{array}{l}\left(\max \left\{\tilde{O}_{E U} ; 1.5\right\} ;+\infty\right), \\
\text { where } x_{E U} \text { is the mean value in the } \\
\text { EU countries }\end{array}$ \\
\hline \multicolumn{4}{|c|}{ Financial capacity of economic entities } \\
\hline 5 & Level of the listing companies capitalization, percent of GDP & Mixed & $(15 ; 150)^{*}$ \\
\hline 6 & Ratio of non-performing loans to total gross loans, percent & Disincentive & $\begin{array}{l}{\left[0 ; \min \left\{\tilde{O}_{E U} ; 7\right\}\right),} \\
\text { where } x_{E U} \text { is the mean value in the } \\
E U \text { countries }\end{array}$ \\
\hline 7 & Credit interest rate, percent & Mixed & $(0 ; 15)^{*}$ \\
\hline 8 & ROA of the enterprises, percent & Incentive & $(0 ;+\infty)$ \\
\hline \multicolumn{4}{|c|}{ Financial capacity of households } \\
\hline 9 & Share of cash income in total household resources, percent & Incentive & 100 \\
\hline 10 & $\begin{array}{l}\text { Ratio of the average old-age pension to the average monthly } \\
\text { nominal wage, percent }\end{array}$ & Mixed & $(67 ; 100)$ \\
\hline 11 & $\begin{array}{l}\text { Share of spending on food and non-alcoholic beverages in total } \\
\text { household spending, percent }\end{array}$ & Disincentive & $(0 ; 20)^{*}$ \\
\hline
\end{tabular}

Note: * Means recommended values on the basis of Methodological Recommendations for Assessing the Level of Economic Security (Kucher, 2014).

tors on how their current year values differ from the

critical ones when compared to the previous year:

$$
y_{-} \text {effect } t_{i}=\left\{\begin{array}{l}
1 . \text { if } x_{i, t} \in\left(x_{i, \text { recom_min }} ; x_{i, \text { recom_max }}\right) \text { and if } \Delta x_{i, t}>\Delta x_{i, t-1} \\
0.67 \text { if } x_{i, t} \in\left(x_{i, \text { recom_min }} ; x_{i, \text { recom_max }}\right) \text { and if } \Delta x_{i, t} \leq \Delta x_{i, t-1} \\
0.33 \text { if } x_{i, t} \notin\left(x_{i, \text { recom_min }} ; x_{i, \text { recom_max }}\right) \text { and if } \Delta x_{i, t}>\Delta x_{i, t-1} \\
0 . \text { if } x_{i, t} \notin\left(x_{i, \text { recom_min }} ; x_{i, \text { recom_max }}\right) \text { and if } \Delta x_{i, t} \leq \Delta x_{i, t-1}
\end{array}\right.
$$

where $y_{-}$effect $t_{i}$ is the score of efficiency indica- Such an approach will make it possible to assess tor, $x_{i}, x_{i, t}$ and $x_{i, t-1}$ are actual values $x_{i}$ in cur- the change in the mixed-type indicators when rent $t$ and previous $t-1$ periods, $x_{i, \text { recom min }}$ and their growth to a certain level indicates a pos$x_{i, \text { recom max }}$ are minimum and maximum recom- itive trend (similar to the incentive indicators), mended values for $x_{i}$, respectively, but at the same time their further growth gives $\Delta x_{i, t}=\min \left\{x_{i, t}-x_{i, \text { recom_min }} ; x_{i, \text { recom_max }}-x_{i, t}\right\}, \quad$ grounds for a negative tendency (similar to the $\Delta x_{i, t-1}=\min \left\{x_{i, t-1}-x_{i, \text { recom_min }} ; x_{i, \text { recom_max }}-x_{i, t-1}\right\}$. 
The use of a scoring of the actual values correspondence to recommended ones and their dynamics provide the opportunity to determine the overall performance indicator of the corresponding component of the state's financial capacity as the arithmetic average of the score for all indicators:

$$
y_{-} \text {effect }=\frac{1}{n} \sum_{i=1}^{n} y_{-} \text {effect } t_{i} \text {, }
$$

where $y_{\text {_effect }}$ is the overall efficiency indicators of the appropriate component of the state's financial capacity.

Based on this and taking into account the share of the corresponding component in the state's financial capacity, one can identify the integral indicator of the creation and use of the state's financial capacity:

$$
\begin{aligned}
& Z=y_{-} \text {effect } \\
& G \\
& +y_{-} \text {effect } W_{H} \cdot W_{H},
\end{aligned}
$$

where $y_{-}$effect $t_{G}, y_{-}$effect $t_{F}$ and $y_{-}$effect $_{H}$ are the overall indicator for efficient creation and use of financial capacity of authorities, economic entities and households, respectively, $W_{G}, W_{F}$ and $W_{H}$ mean the proportion of financial capacity of authorities, economic entities and households in overall financial capacity of the state.

The range of values of the integral indicator of the efficient formation and use of the state's financial capacity ranges from 0 to 1 . Based on the approach used in the Methodological Recommendations for Calculating the Level of Economic Security of Ukraine (Kucher, 2014), five intervals are allocated, which makes it possible to determine a rating of the state's financial capacity (see Table 2).

According to the scientific and methodological proposed approach and using the existing infor- mation base, it is envisaged to calculate the indicators of the status and indicators of the efficient creation and use of the state's financial capacity components, score, summarize the estimates for each of the components, calculate the integral indicator of the efficient creation and use of the state's financial capacity, as well as to define the rating assessment of the state's financial capacity and to make adequate conclusions and propositions.

Figure 2 diagrammatizes the proposed scientific and methodological approach to assessing the financial capacity of the state.

Let's define general indicator of the efficient creation and use of the financial capacity of authorities. To do this, the balance of the state budget of Ukraine and the EU countries is compared (see Table 3).

The minimum value of this indicator among the EU countries was observed in Greece (2008-2009, 2015), Ireland (2010-2011), Spain (2012, 2016 2017), Slovenia (2013) and Cyprus (2014). The maximums are in Finland (2008), Luxembourg (2009, 2012-2016), Estonia (2010-2011) and Malta (2017). In Ukraine, it complied with pan-European tendencies, as evidenced by a slight rupture for values in Ukraine and across the EU countries in general. In addition, in recent years, the positive dynamics of reducing the level of the state budget deficit have been observed. However, in 2013-2017, its value was beyond the recommended scope.

The restriction of the government debt amount $(60 \%$ at most) is another criterion for candidates for joining the euro zone. Given the European orientation of Ukraine's development, this provision is enshrined in Article 18 of the Budget Code (Verkhovna Rada of Ukraine, 2010).

The relative amount of the government debt in Ukraine (see Table 4) and the EU countries began

Table 2. Scale of rating assessments of the level of creation and use of the state's financial capacity

Source: Developed by the authors.

\begin{tabular}{c:c:c}
\hline No. & Z-value & Rating \\
\hline 1 & {$[0.8 ; 1]$} & A (optimum level of efficient creation and use of the state's financial capacity) \\
\hline 2 & {$[0.6 ; 0.8)$} & B (sufficient level of efficient creation and use of the state's financial capacity) \\
\hdashline 3 & {$[0.4 ; 0.6)$} & C (satisfactory level of efficient creation and use of the state's financial capacity) \\
\hdashline 4 & {$[0.2 ; 0.4)$} & D (unsatisfactory level of efficient creation and use of the state's financial capacity) \\
\hdashline 5 & {$[0 ; 0.2)$} & F (critical level of efficient creation and use of the state's financial capacity) \\
\hline
\end{tabular}




\section{INFORMATION BASE:}

Data from the Ministry of Finance of Ukraine, the National Bank of Ukraine, the State Statistics Service of Ukraine, Eurostat, and the World Bank Group

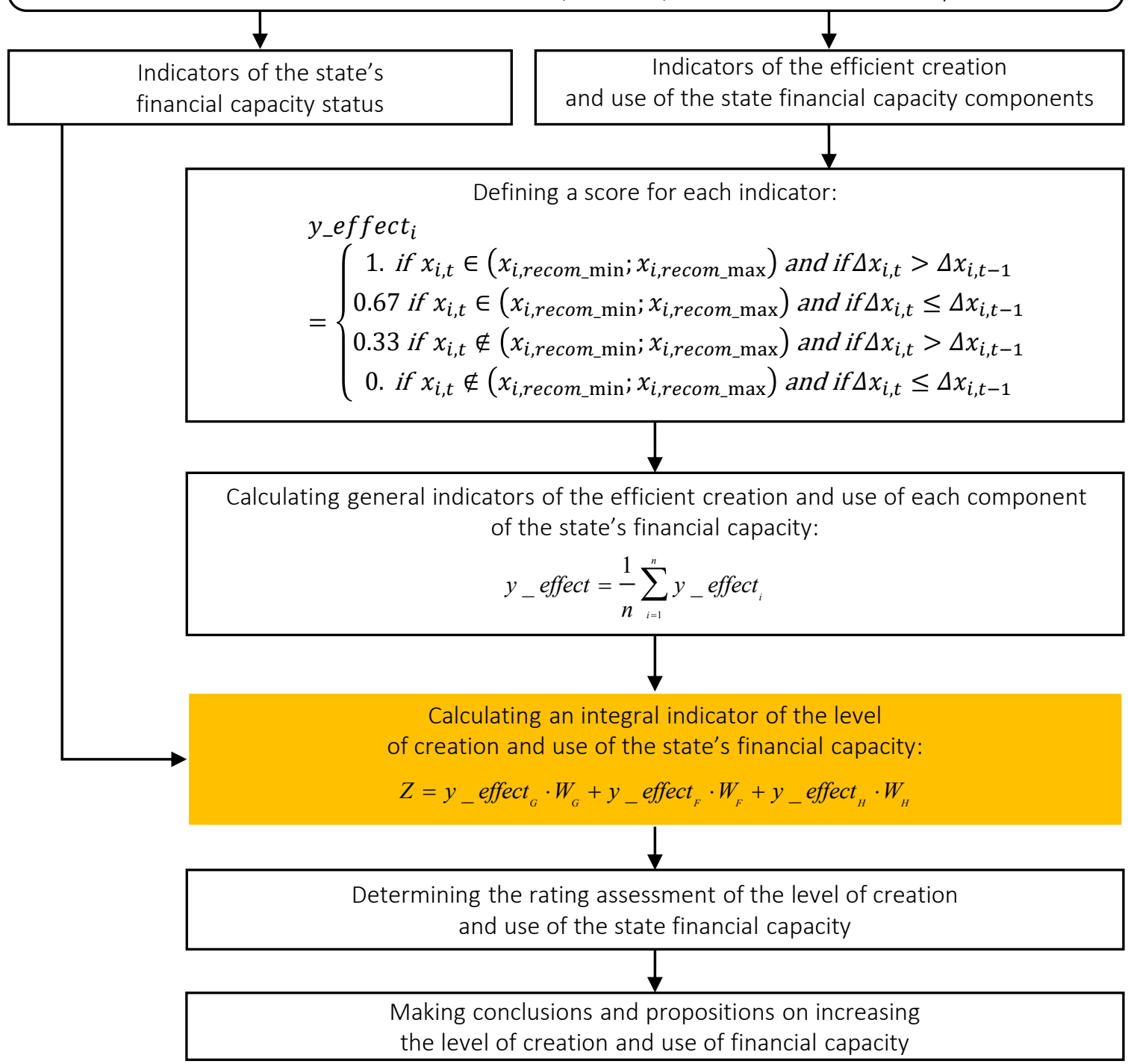

Figure 2. Scientific and methodological approach to determining the level of creation and use of the state's financial capacity

Table 3. The ratio of the state budget balance to GDP in Ukraine and the EU countries in 2008-2017, \%

Source: Compiled by the authors based on the State Statistics Service of Ukraine, Ministry of Finance of Ukraine and Eurostat data.

\begin{tabular}{|c|c|c|c|c|c|c|c|c|c|c|c|}
\hline \multirow{2}{*}{ No. } & \multirow{2}{*}{ Country } & \multicolumn{10}{|c|}{ Years } \\
\hline & & 2008 & 2009 & 2010 & 2011 & 2012 & 2013 & 2014 & 2015 & 2016 & 2017 \\
\hline 1 & Austria & -1.5 & -5.3 & -4.4 & -2.6 & -2.2 & -2.0 & -2.7 & -1.0 & -1.6 & -0.8 \\
\hline 2 & Belgium & -1.1 & -5.4 & -4.0 & -4.2 & -4.2 & -3.1 & -3.1 & -2.5 & -2.4 & -0.9 \\
\hline 3 & Bulgaria & 1.6 & -4.1 & -3.1 & -2.0 & -0.3 & -0.4 & -5.4 & -1.7 & 0.2 & 1.1 \\
\hline 4 & Great Britain & -5.2 & -10.1 & -9.3 & -7.5 & -8.1 & -5.4 & -5.4 & -4.2 & -2.9 & -1.8 \\
\hline 5 & Greece & -10.2 & -15.1 & -11.2 & -10.3 & -8.9 & -13.2 & -3.6 & -5.6 & 0.5 & 0.8 \\
\hline 6 & Denmark & 3.2 & -2.8 & -2.7 & -2.1 & -3.5 & -1.2 & 1.1 & -1.5 & -0.4 & 1.1 \\
\hline 7 & Estonia & -2.7 & -2.2 & 0.2 & 1.2 & -0.3 & -0.2 & 0.7 & 0.1 & -0.3 & -0.4 \\
\hline 8 & Ireland & -7.0 & -13.8 & -32.0 & -12.8 & -8.1 & -6.1 & -3.6 & -1.9 & -0.5 & -0.2 \\
\hline
\end{tabular}


Table 3 (cont.). The ratio of the state budget balance to GDP in Ukraine and the EU countries in $2008-2017, \%$

\begin{tabular}{|c|c|c|c|c|c|c|c|c|c|c|c|}
\hline \multirow{2}{*}{ No. } & \multirow{2}{*}{ Country } & \multicolumn{10}{|c|}{ Years } \\
\hline & & 2008 & 2009 & 2010 & 2011 & 2012 & 2013 & 2014 & 2015 & 2016 & 2017 \\
\hline 9 & Spain & -4.4 & -11.0 & -9.4 & -9.6 & -10.5 & -7.0 & -6.0 & -5.3 & -4.5 & -3.1 \\
\hline 10 & Italy & -2.6 & -5.2 & -4.2 & -3.7 & -2.9 & -2.9 & -3.0 & -2.6 & -2.5 & -2.4 \\
\hline 11 & Cyprus & 0.9 & -5.4 & -4.7 & -5.7 & -5.6 & -5.1 & -9.0 & -1.3 & 0.3 & 1.8 \\
\hline 12 & Latvia & -4.2 & -9.1 & -8.7 & -4.3 & -1.2 & -1.2 & -1.5 & -1.4 & 0.1 & -0.6 \\
\hline 13 & Lithuania & -3.1 & -9.1 & -6.9 & -8.9 & -3.1 & -2.6 & -0.6 & -0.3 & 0.3 & 0.5 \\
\hline 14 & Luxembourg & 3.3 & -0.7 & -0.7 & 0.5 & 0.3 & 1.0 & 1.3 & 1.3 & 1.6 & 1.4 \\
\hline 15 & Malta & -4.2 & -3.2 & -2.4 & -2.4 & -3.5 & -2.4 & -1.7 & -1.0 & 0.9 & 3.5 \\
\hline 16 & Netherlands & 0.2 & -5.1 & -5.2 & -4.4 & -3.9 & -2.9 & -2.2 & -2.0 & 0.0 & 1.2 \\
\hline 17 & Germany & -0.2 & -3.2 & -4.2 & -1.0 & 0.0 & -0.1 & 0.6 & 0.8 & 0.9 & 1.0 \\
\hline 18 & Poland & -3.6 & -7.3 & -7.3 & -4.8 & -3.7 & -4.1 & -3.7 & -2.7 & -2.2 & -1.4 \\
\hline 19 & Portugal & -3.8 & -9.8 & -11.2 & -7.4 & -5.7 & -4.8 & -7.2 & -4.4 & -2.0 & -3.0 \\
\hline 20 & Romania & -5.4 & -9.1 & -6.9 & -5.4 & -3.7 & -2.2 & -1.3 & -0.7 & -2.9 & -2.9 \\
\hline 21 & Slovakia & -2.4 & -7.8 & -7.5 & -4.3 & -4.3 & -2.7 & -2.7 & -2.6 & -2.2 & -0.8 \\
\hline 22 & Slovenia & -1.4 & -5.8 & -5.6 & -6.7 & -4.0 & -14.7 & -5.5 & -2.8 & -1.9 & 0.1 \\
\hline 23 & Hungary & -3.7 & -4.5 & -4.5 & -5.4 & -2.4 & -2.6 & -2.6 & -1.9 & -1.6 & -2.2 \\
\hline 24 & Finland & 4.2 & -2.5 & -2.6 & -1.0 & -2.2 & -2.6 & -3.2 & -2.8 & -1.7 & -0.7 \\
\hline 25 & France & -3.3 & -7.2 & -6.9 & -5.2 & -5.0 & -4.1 & -3.9 & -3.6 & -3.5 & -2.7 \\
\hline 26 & Croatia & -2.8 & -6.0 & -6.3 & -7.9 & -5.3 & -5.3 & -5.1 & -3.4 & -0.9 & 0.9 \\
\hline 27 & Czech Republic & -2.0 & -5.5 & -4.2 & -2.7 & -3.9 & -1.2 & -2.1 & -0.6 & 0.7 & 1.5 \\
\hline 28 & Sweden & 1.9 & -0.7 & 0.0 & -0.2 & -1.0 & -1.4 & -1.6 & 0.2 & 1.1 & 1.6 \\
\hline 29 & EU, mean value & -2.5 & -6.6 & -6.4 & -4.6 & -4.3 & -3.3 & -2.9 & -2.3 & -1.7 & -1.0 \\
\hline 30 & Ukraine & -1.3 & -3.9 & -5.9 & -1.8 & -3.8 & -4.4 & -5.0 & -2.3 & -2.9 & -1.6 \\
\hline 31 & Deviation from mean value in the EU & +1.2 & +2.7 & +0.5 & +2.8 & +0.5 & -1.1 & -2.1 & 0 & -1.2 & -0.6 \\
\hline
\end{tabular}

Note: Negative values are for countries with budget deficit.

to grow after the global financial crisis, whereas since 2014, only in Ukraine (from $40.2 \%$ in 2013 to $70.3 \%$ in 2014 ) its most rapid growth was observed. This was caused by the political and economic crisis, the military conflict, the difficult financial situation of certain state-owned enterprises and banks.
Greece had the most difficult situation among the European countries. The indices of government debt were the highest over the entire analyzed period in the country. Estonia was the least dependent on lenders. In 2008-2017, Estonia had the lowest level of government debt among all countries. As a whole, the level of

Table 4. The government debt to GDP ratio in Ukraine and the EU countries in 2008-2017, \%

Source: Compiled by the authors based on the State Statistics Service of Ukraine, Ministry of Finance of Ukraine and Eurostat data.

\begin{tabular}{|c|c|c|c|c|c|c|c|c|c|c|c|}
\hline \multirow{2}{*}{ No. } & \multirow{2}{*}{ Country } & \multicolumn{10}{|c|}{ Years } \\
\hline & & 2008 & 2009 & 2010 & 2011 & 2012 & 2013 & 2014 & 2015 & 2016 & 2017 \\
\hline 1 & Austria & 68.7 & 79.9 & 82.7 & 82.4 & 81.9 & 81.3 & 84.0 & 84.8 & 83.0 & 78.3 \\
\hline 2 & Belgium & 92.5 & 99.5 & 99.7 & 102.6 & 104.3 & 105.5 & 107.6 & 106.5 & 106.1 & 103.4 \\
\hline 3 & Bulgaria & 13.0 & 13.7 & 15.3 & 15.2 & 16.7 & 17.1 & 27.1 & 26.2 & 29.6 & 25.6 \\
\hline 4 & Great Britain & 49.7 & 63.7 & 75.2 & 80.8 & 84.1 & 85.2 & 87.0 & 87.9 & 87.9 & 87.4 \\
\hline 5 & Greece & 109.4 & 126.7 & 146.2 & 172.1 & 159.6 & 177.4 & 178.9 & 175.9 & 178.5 & 176.1 \\
\hline 6 & Denmark & 33.3 & 40.2 & 42.6 & 46.1 & 44.9 & 44.0 & 44.3 & 39.9 & 37.9 & 36.1 \\
\hline 7 & Estonia & 4.5 & 7.0 & 6.6 & 6.1 & 9.7 & 10.2 & 10.5 & 9.9 & 9.2 & 8.7 \\
\hline 8 & Ireland & 42.4 & 61.5 & 86.0 & 110.9 & 119.9 & 119.7 & 104.1 & 76.8 & 73.4 & 68.4 \\
\hline 9 & Spain & 39.5 & 52.8 & 60.1 & 69.5 & 85.7 & 95.5 & 100.4 & 99.3 & 99.0 & 98.1 \\
\hline 10 & Italy & 102.4 & 112.5 & 115.4 & 116.5 & 123.4 & 129.0 & 131.8 & 131.6 & 131.4 & 131.2 \\
\hline 11 & Cyprus & 45.6 & 54.3 & 56.8 & 66.2 & 80.1 & 103.1 & 108.0 & 108.0 & 105.5 & 96.1 \\
\hline 12 & Latvia & 18.2 & 35.8 & 46.8 & 42.7 & 41.2 & 39.0 & 40.9 & 36.8 & 40.3 & 40.0 \\
\hline 13 & Lithuania & 14.6 & 28.0 & 36.2 & 37.2 & 39.8 & 38.8 & 40.5 & 42.6 & 39.9 & 39.4 \\
\hline
\end{tabular}


Table 4 (cont.). The government debt to GDP ratio in Ukraine and the EU countries in 2008-2017, \%

\begin{tabular}{|c|c|c|c|c|c|c|c|c|c|c|c|}
\hline \multirow{2}{*}{ No. } & \multirow{2}{*}{ Country } & \multicolumn{10}{|c|}{ Years } \\
\hline & & 2008 & 2009 & 2010 & 2011 & 2012 & 2013 & 2014 & 2015 & 2016 & 2017 \\
\hline 14 & Luxembourg & 14.9 & 15.7 & 19.8 & 18.7 & 22.0 & 23.7 & 22.7 & 22.2 & 20.7 & 23.0 \\
\hline 15 & Malta & 62.6 & 67.6 & 67.5 & 70.1 & 67.7 & 68.4 & 63.7 & 58.6 & 56.3 & 50.9 \\
\hline 16 & Netherlands & 54.7 & 56.8 & 59.3 & 61.7 & 66.2 & 67.7 & 67.9 & 64.6 & 61.9 & 57.0 \\
\hline 17 & Germany & 65.2 & 72.6 & 81.0 & 78.6 & 79.9 & 77.4 & 74.5 & 70.8 & 67.9 & 63.9 \\
\hline 18 & Poland & 46.3 & 49.4 & 53.1 & 54.1 & 53.7 & 55.7 & 50.4 & 51.3 & 54.2 & 50.6 \\
\hline 19 & Portugal & 71.7 & 83.6 & 96.2 & 111.4 & 126.2 & 129.0 & 130.6 & 128.8 & 129.2 & 124.8 \\
\hline 20 & Romania & 12.4 & 22.1 & 29.7 & 34.0 & 36.9 & 37.6 & 39.2 & 37.8 & 37.3 & 35.1 \\
\hline 21 & Slovakia & 28.5 & 36.3 & 41.2 & 43.7 & 52.2 & 54.7 & 53.5 & 52.2 & 51.8 & 50.9 \\
\hline 22 & Slovenia & 21.8 & 34.6 & 38.4 & 46.6 & 53.8 & 70.4 & 80.4 & 82.6 & 78.7 & 74.1 \\
\hline 23 & Hungary & 71.6 & 77.8 & 80.2 & 80.5 & 78.4 & 77.1 & 76.6 & 76.6 & 75.9 & 73.3 \\
\hline 24 & Finland & 32.7 & 41.7 & 47.1 & 48.5 & 53.9 & 56.5 & 60.2 & 63.6 & 63.0 & 61.3 \\
\hline 25 & France & 68.8 & 83.0 & 85.3 & 87.8 & 90.6 & 93.4 & 94.9 & 95.6 & 98.2 & 98.5 \\
\hline 26 & Croatia & 39.0 & 48.3 & 57.3 & 63.8 & 69.4 & 80.4 & 84.0 & 83.7 & 80.2 & 77.5 \\
\hline 27 & Czech Republic & 28.3 & 33.6 & 37.4 & 39.8 & 44.5 & 44.9 & 42.2 & 40.0 & 36.8 & 34.7 \\
\hline 28 & Sweden & 37.7 & 41.3 & 38.6 & 37.8 & 38.1 & 40.7 & 45.5 & 44.2 & 42.4 & 40.8 \\
\hline 29 & EU, mean value & 60.7 & 73.3 & 78.8 & 81.4 & 83.8 & 85.7 & 86.4 & 84.4 & 83.3 & 81.6 \\
\hline 30 & Ukraine & 20.0 & 34.7 & 39.9 & 35.9 & 36.6 & 40.2 & 70.3 & 79.4 & 81.0 & 71.8 \\
\hline 31 & Deviation from mean value in the EU & -40.7 & -38.6 & -38.9 & -45.5 & -47.2 & -45.5 & -16.1 & -5.0 & -2.3 & -9.8 \\
\hline
\end{tabular}

government debt in Ukraine did not exceed the average for EU countries, however, the credibility of Ukraine as a borrower is much lower than in other European countries, and the cost of debt servicing is higher.

The role of the state in redistributive relations in society can be characterized by the consolidated budget revenues to GDP ratio (see Figure 3).
During 2008-2017, the value of the indicator varied within the range of $29.1-34.1 \%$ and did not exceed the critical level (37\%), although it was significant and the budget accounted for about one third of GDP. Taking into account the role of the authorities in overcoming the military conflict consequences and, accordingly, the need to finance appropriate measures, as evidenced by foreign experience, it can be assumed that the level

Source: Calculated by the authors based on the State Statistics Service of Ukraine and the Ministry of Finance of Ukraine data.

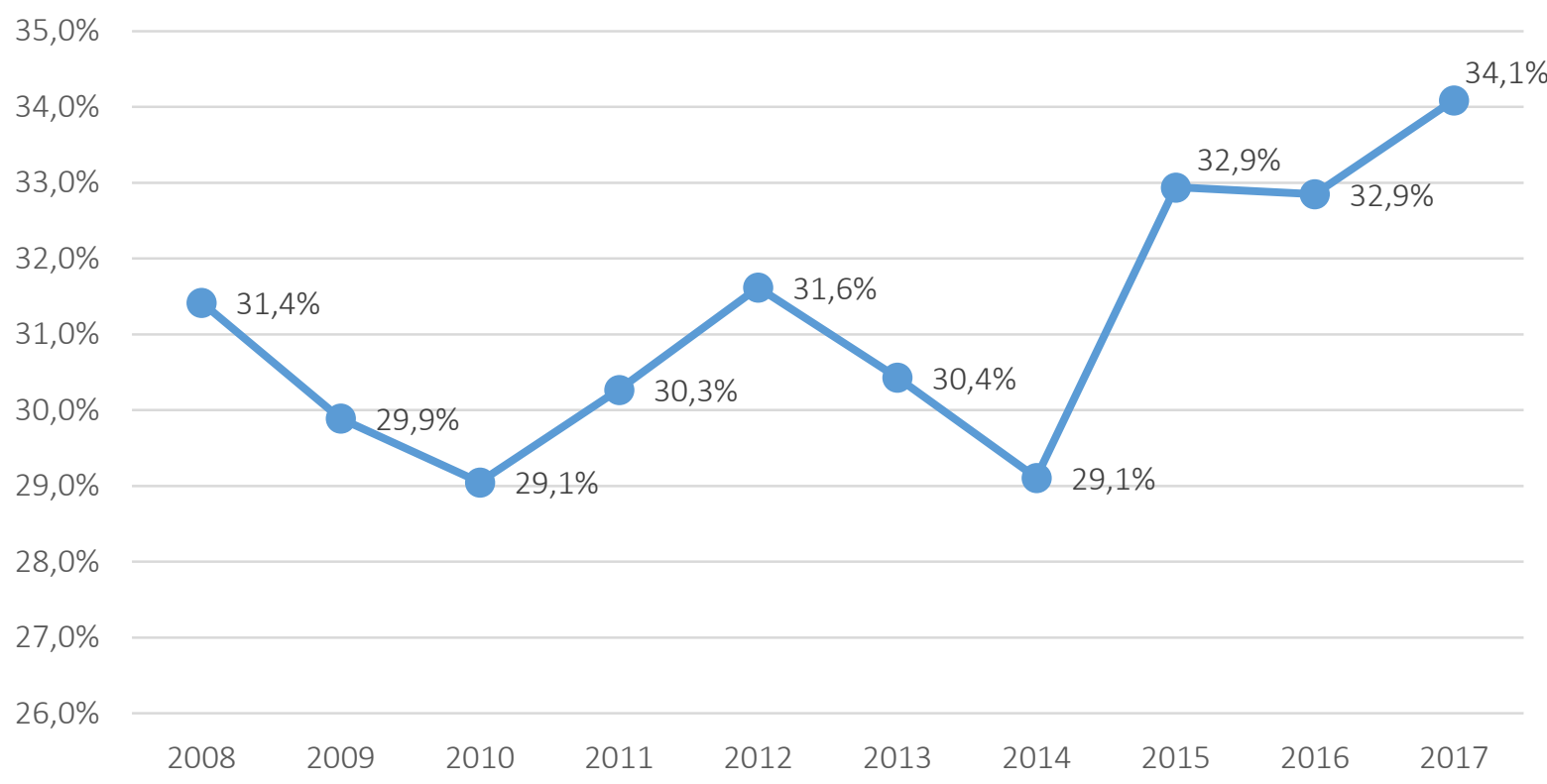

Figure 3. The level of GDP redistribution through the consolidated budget in 2008-2017, \% 
of budget centralization of GDP will continue to tend to slightly increase.

Given the high dependence of the domestic economy on foreign trade, special attention should be paid to the study of sufficiency of gold and foreign exchange reserves to finance imports under limited exports.

While comparing the value of the indicator in Ukraine and EU countries, the following should be noted (see Table 5):

1) gradual reduction of domestic gold and foreign exchange reserves compared to imports of goods and services, while the critical value of this indicator was in 2014 (1.2 months of imports) and since then their growth has been observed;

2) the highest ratio was in Romania (2008-2012), Croatia (2013-2014), Bulgaria (2015-2016) and the Czech Republic (2017);

3) the minimum value of the indicator was observed in Luxembourg and ranged within 0.02 to 0.05 months of imports;

4) the EU's gold and foreign exchange reserves amounted generally to an average of 2-3 months of imports;

5) the largest deviation from the average indicator in the EU was in 2010, and the smallest in 2015.

Table 5. Gold and foreign exchange reserves in Ukraine and the EU in 2008-2017, months of imports

Source: The World Bank Group data (n.d.).

\begin{tabular}{|c|c|c|c|c|c|c|c|c|c|c|c|}
\hline \multirow{2}{*}{ No. } & \multirow{2}{*}{ Country } & \multicolumn{10}{|c|}{ Years } \\
\hline & & 2008 & 2009 & 2010 & 2011 & 2012 & 2013 & 2014 & 2015 & 2016 & 2017 \\
\hline 1 & Austria & 0.77 & 1.03 & 1.20 & 1.11 & 1.30 & 1.15 & 1.19 & 1.27 & 1.25 & 1.06 \\
\hline 2 & Belgium & 0.36 & 0.70 & 0.75 & 0.70 & 0.78 & 0.66 & 0.61 & 0.70 & 0.64 & 0.67 \\
\hline 3 & Bulgaria & 4.77 & 7.42 & 7.10 & 5.59 & 6.68 & 6.02 & 6.10 & 7.61 & 8.46 & 8.71 \\
\hline 4 & Great Britain & 0.54 & 0.98 & 1.15 & 1.15 & 1.23 & 1.21 & 1.24 & 1.60 & 1.54 & 1.66 \\
\hline 5 & Greece & 0.29 & 0.64 & 0.79 & 0.79 & 1.13 & 0.78 & 0.82 & 1.09 & 1.31 & 1.31 \\
\hline 6 & Denmark & 2.38 & 5.77 & 5.69 & 5.47 & 6.05 & 5.70 & 4.79 & 4.69 & 4.67 & 5.09 \\
\hline 7 & Estonia & 2.32 & 3.78 & 1.98 & 0.12 & 0.17 & 0.17 & 0.23 & 0.27 & 0.22 & 0.20 \\
\hline 8 & Ireland & 0.04 & 0.09 & 0.09 & 0.07 & 0.07 & 0.07 & 0.06 & 0.07 & 0.10 & 0.12 \\
\hline 9 & Spain & 0.38 & 0.74 & 0.81 & 1.05 & 1.31 & 1.19 & 1.23 & 1.51 & 1.75 & 1.75 \\
\hline 10 & Italy & 1.58 & 2.63 & 2.87 & 2.72 & 3.34 & 2.70 & 2.62 & 2.78 & 2.90 & 2.93 \\
\hline 11 & Cyprus & 0.42 & 0.60 & 0.49 & 0.51 & 0.65 & 0.54 & 0.52 & 0.32 & 0.47 & 0.34 \\
\hline 12 & Latvia & 2.95 & 7.25 & 6.44 & 3.95 & 4.45 & 4.49 & 1.83 & 2.29 & 2.35 & 2.68 \\
\hline 13 & Lithuania & 2.14 & 3.91 & 2.96 & 2.68 & 2.76 & 2.37 & 2.62 & 0.60 & 0.92 & 1.33 \\
\hline 14 & Luxembourg & 0.02 & 0.05 & 0.05 & 0.04 & 0.03 & 0.03 & 0.03 & 0.03 & 0.04 & 0.03 \\
\hline 15 & Malta & 0.16 & 0.27 & 0.28 & 0.21 & 0.30 & 0.24 & 0.25 & 0.27 & 0.31 & 0.38 \\
\hline 16 & Netherlands & 0.37 & 0.64 & 0.67 & 0.65 & 0.75 & 0.61 & 0.53 & 0.53 & 0.51 & 0.53 \\
\hline 17 & Germany & 1.00 & 1.65 & 1.77 & 1.64 & 1.88 & 1.44 & 1.38 & 1.43 & 1.49 & 1.48 \\
\hline 18 & Poland & 2.91 & 4.97 & 4.87 & 4.37 & 5.11 & 4.82 & 4.22 & 4.55 & 5.29 & 4.54 \\
\hline 19 & Portugal & 1.05 & 1.78 & 2.20 & 2.11 & 2.73 & 2.08 & 2.21 & 2.50 & 3.19 & 2.97 \\
\hline 20 & Romania & 5.12 & 8.68 & 8.44 & 6.88 & 7.15 & 6.88 & 5.83 & 5.75 & 5.48 & 5.26 \\
\hline 21 & Slovakia & 2.51 & 0.33 & 0.34 & 0.32 & 0.35 & 0.28 & 0.33 & 0.41 & 0.40 & 0.46 \\
\hline 22 & Slovenia & 0.27 & 0.43 & 0.40 & 0.31 & 0.34 & 0.32 & 0.34 & 0.32 & 0.26 & 0.28 \\
\hline 23 & Hungary & 2.65 & 4.52 & 4.30 & 4.29 & 4.34 & 4.41 & 3.76 & 3.43 & 2.63 & 2.52 \\
\hline 24 & Finland & 0.69 & 1.36 & 1.05 & 0.95 & 1.07 & 1.08 & 1.03 & 1.19 & 1.21 & 1.11 \\
\hline 25 & France & 1.14 & 1.86 & 2.20 & 1.95 & 2.24 & 1.72 & 1.67 & 1.81 & 1.90 & 1.91 \\
\hline 26 & Croatia & 4.17 & 6.51 & 6.56 & 6.05 & 6.73 & 7.91 & 6.52 & 7.37 & 6.40 & 7.29 \\
\hline 27 & Czech Republic & 2.70 & 3.79 & 3.40 & 2.78 & 3.21 & 4.00 & 3.67 & 4.90 & 6.47 & 10.03 \\
\hline 28 & Sweden & 1.26 & 2.74 & 2.38 & 2.10 & 2.32 & 2.86 & 2.66 & 2.88 & 2.92 & 2.86 \\
\hline 29 & EU, mean value & 1.75 & 2.96 & 2.90 & 2.60 & 2.94 & 2.82 & 2.49 & 2.70 & 2.97 & 3.46 \\
\hline 30 & Ukraine & 3.65 & 5.20 & 5.43 & 3.70 & 2.66 & 2.26 & 1.17 & 2.87 & 3.22 & 3.26 \\
\hline 31 & Deviation from mean value in the EU & -1.9 & -2.24 & -2.53 & -1.1 & 0.28 & 0.56 & 1.32 & -0.17 & -0.25 & 0.2 \\
\hline
\end{tabular}


Table 6. Indicators of the efficient creation and use of Ukrainian authorities' financial capacity in 2008-2017

Source: Calculated by the authors.

\begin{tabular}{|c|c|c|c|c|c|c|c|c|c|c|c|}
\hline \multirow{2}{*}{ No. } & \multirow{2}{*}{ Indicator } & \multicolumn{10}{|c|}{ Years } \\
\hline & & 2008 & 2009 & 2010 & 2011 & 2012 & 2013 & 2014 & 2015 & 2016 & 2017 \\
\hline 1 & $\begin{array}{l}\text { The government budget deficit/surplus } \\
\text { to GDP ratio }\end{array}$ & 1 & 0.67 & 0.67 & 1 & 0.67 & 0 & 0 & 0.33 & 0 & 0.33 \\
\hline 2 & $\begin{array}{l}\text { The amount of government and } \\
\text { government-guaranteed debt to GDP } \\
\text { ratio }\end{array}$ & 1 & 1 & 0.67 & 1 & 0.67 & 0.67 & 0 & 0 & 0 & 0.33 \\
\hline 3 & $\begin{array}{l}\text { The level of GDP redistribution through } \\
\text { the consolidated budget }\end{array}$ & 0.67 & 1 & 1 & 0.67 & 0.67 & 1 & 1 & 0.67 & 1 & 0.67 \\
\hline 4 & Gross international reserves & 0.67 & 1 & 1 & 0.67 & 0 & 0 & 0 & 1 & 1 & 0.33 \\
\hline 5 & $\begin{array}{l}\text { Overall efficiency indicator of the } \\
\text { authorities' financial capacity }\end{array}$ & 0.835 & 0.918 & 0.835 & 0.835 & 0.503 & 0.418 & 0.25 & 0.5 & 0.5 & 0.415 \\
\hline
\end{tabular}

Generally, the authorities' financial capacity was susceptible to the effects of the global financial crisis affecting Ukraine, as well as the more complex early 2014 crisis, which included radical transformations in many aspects of society's activities. The overall indicator of the efficient creation and use of financial capacity of the Ukrainian authorities in 2008-2017 is calculated (see Table 6).

The next step is to calculate the overall indicator of the efficient creation and use of economic entities' financial capacity.

In this regard, the dynamics of changes in credit interest rates was estimated (see Figure 4). The analysis gives grounds for asserting that interest rates remained at a relatively stable level within the range of 15.87 to $21.82 \%$, while they were significantly higher compared to the average in the EU countries, fluctuating within 6.1 to $7.6 \%$.
The high level of interest rates in Ukraine is due to high risk and decrease in the financial position of borrowers. Accordingly, the ratio of non-performing loans to total gross loans in $2008-2017$ is considered (see Table 7).

The data suggest that Ukraine has a clear tendency to increase the share of non-performing loans to total gross loans from $3.88 \%$ in 2008 to $54.54 \%$ in 2017, while in the EU countries, their share fluctuated within the 2 to $6 \%$.

Along with bank loans, the attraction of financial resources as a result of the security issue, in particular shares and bonds, may be of key importance in capital mobilization of enterprises. The level of listing companies capitalization (the ratio of capitalization of listing companies to GDP) is, for example, one of the indicators of success in the of financial resources creation.

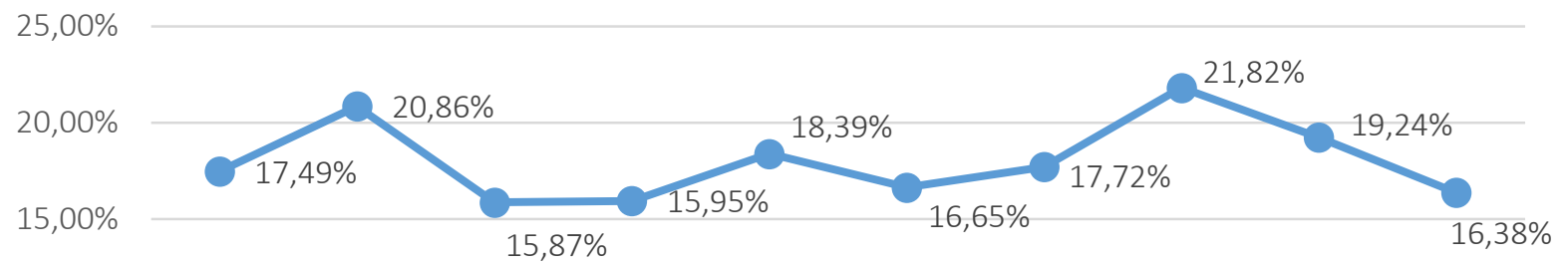

$10,00 \%$

$5,00 \%$

$0,00 \%$ $\begin{array}{llllllll}2008 & 2009 & 2010 & 2011 & 2012 & 2013 & 2014 & 2015\end{array} 2016 \quad 2017$

Figure 4. Credit interest rates in Ukraine in 2008-2017 
Table 7. The ratio of non-performing loans to aggregate gross loans in Ukraine and the EU countries in $2008-2017, \%$

Source: Compiled based on the World Bank Group data (n.d.).

\begin{tabular}{|c|c|c|c|c|c|c|c|c|c|c|c|}
\hline \multirow{2}{*}{ No. } & \multirow{2}{*}{ Country } & \multicolumn{10}{|c|}{ Years } \\
\hline & & 2008 & 2009 & 2010 & 2011 & 2012 & 2013 & 2014 & 2015 & 2016 & 2017 \\
\hline 1 & Austria & 1.90 & 2.25 & 2.83 & 2.71 & 2.81 & 2.87 & 3.47 & 3.39 & 2.70 & 2.37 \\
\hline 2 & Belgium & 1.65 & 3.08 & 2.80 & 3.30 & 3.74 & 4.24 & 4.18 & 3.79 & 3.43 & 2.92 \\
\hline 3 & Bulgaria & 2.40 & 6.42 & 11.92 & 14.97 & 16.63 & 16.88 & 16.75 & 14.61 & 13.17 & 10.43 \\
\hline 4 & Great Britain & 1.56 & 3.51 & 3.95 & 3.96 & 3.59 & 3.11 & 1.65 & 1.01 & 0.94 & 0.73 \\
\hline 5 & Greece & 4.67 & 6.95 & 9.12 & 14.43 & 23.27 & 31.90 & 33.78 & 36.65 & 36.30 & 45.57 \\
\hline 6 & Denmark & $\mathrm{n} / \mathrm{a}$ & $\mathrm{n} / \mathrm{a}$ & 4.07 & 3.66 & 5.95 & 4.62 & 4.40 & 3.69 & 3.21 & 2.48 \\
\hline 7 & Estonia & 1.94 & 5.20 & 5.38 & 4.05 & 2.62 & 1.47 & 1.39 & 0.98 & 0.87 & 0.70 \\
\hline 8 & Ireland & 1.92 & 9.80 & 13.05 & 16.12 & 24.99 & 25.71 & 20.65 & 14.93 & 13.61 & 11.46 \\
\hline 9 & Spain & 2.81 & 4.12 & 4.67 & 6.01 & 7.48 & 9.38 & 8.45 & 6.16 & 5.64 & 4.46 \\
\hline 10 & Italy & 6.28 & 9.45 & 10.03 & 11.74 & 13.75 & 16.54 & 18.03 & 18.06 & 17.12 & 14.38 \\
\hline 11 & Cyprus & 3.59 & 4.51 & 5.82 & 9.99 & 18.37 & 38.56 & 44.97 & 47.75 & 48.68 & 40.17 \\
\hline 12 & Latvia & 2.10 & 14.28 & 15.93 & 14.05 & 8.72 & 6.41 & 4.60 & 4.64 & 6.26 & 5.51 \\
\hline 13 & Lithuania & 6.08 & 23.99 & 23.33 & 18.84 & 14.80 & 11.59 & 8.19 & 4.95 & 3.66 & 3.18 \\
\hline 14 & Luxembourg & $\mathrm{n} / \mathrm{a}$ & 0.67 & 0.25 & 0.38 & 0.15 & 0.21 & $n / a$ & $\mathrm{n} / \mathrm{a}$ & 0.90 & 0.79 \\
\hline 15 & Malta & 5.01 & 5.78 & 7.02 & 7.09 & 7.75 & 8.95 & 9.05 & 6.77 & 5.32 & 4.07 \\
\hline 16 & Netherlands & 1.68 & 3.20 & 2.83 & 2.71 & 3.10 & 3.23 & 2.98 & 2.71 & 2.54 & 2.31 \\
\hline 17 & Germany & 2.85 & 3.31 & 3.20 & 3.03 & 2.86 & 2.70 & 2.34 & 1.97 & 1.71 & 1.50 \\
\hline 18 & Poland & 2.82 & 4.29 & 4.91 & 4.66 & 5.20 & 4.98 & 4.82 & 4.34 & 4.05 & 3.94 \\
\hline 19 & Portugal & 3.60 & 5.13 & 5.31 & 7.47 & 9.74 & 10.62 & 11.91 & 17.48 & 17.18 & 13.27 \\
\hline 20 & Romania & 2.75 & 7.89 & 11.85 & 14.33 & 18.24 & 21.87 & 13.94 & 13.51 & 9.62 & 6.41 \\
\hline 21 & Slovakia & 2.49 & 5.29 & 5.84 & 5.61 & 5.22 & 5.14 & 5.35 & 4.87 & 4.44 & 3.70 \\
\hline 22 & Slovenia & 4.22 & 5.79 & 8.21 & 11.81 & 15.18 & 13.31 & 11.73 & 9.96 & 5.07 & 3.20 \\
\hline 23 & Hungary & 3.23 & 8.24 & 10.04 & 13.68 & 16.04 & 16.83 & 15.62 & 11.66 & 7.42 & 4.17 \\
\hline 24 & Finland & $\mathrm{n} / \mathrm{a}$ & $\mathrm{n} / \mathrm{a}$ & $\mathrm{n} / \mathrm{a}$ & $\mathrm{n} / \mathrm{a}$ & $n / a$ & $\mathrm{n} / \mathrm{a}$ & 1.30 & 1.34 & 1.52 & 1.67 \\
\hline 25 & France & 2.82 & 4.02 & 3.76 & 4.29 & 4.29 & 4.50 & 4.16 & 3.98 & 3.64 & 3.08 \\
\hline 26 & Croatia & 4.87 & 7.66 & 11.09 & 12.27 & 13.76 & 15.43 & 16.71 & 16.33 & 13.61 & 11.20 \\
\hline 27 & Czech Republic & 2.81 & 4.58 & 5.39 & 5.22 & 5.24 & 5.20 & 5.61 & 5.48 & 4.59 & 3.74 \\
\hline 28 & Sweden & 0.46 & 0.83 & 0.78 & 0.65 & 0.70 & 0.61 & 1.24 & 1.17 & 1.06 & 1.12 \\
\hline 29 & EU, mean value & 2.81 & 5.17 & 5.39 & 6.01 & 7.48 & 6.41 & 5.48 & 4.91 & 4.52 & 3.72 \\
\hline 30 & Ukraine & 3.88 & 13.70 & 15.27 & 14.73 & 16.54 & 12.89 & 18.98 & 28.03 & 30.47 & 54.54 \\
\hline 31 & $\begin{array}{l}\text { Deviation from mean value } \\
\text { in the EU }\end{array}$ & -1.07 & -8.53 & -9.88 & -8.72 & -9.06 & -6.48 & -13.50 & -23.12 & -25.95 & -50.82 \\
\hline
\end{tabular}

The analysis of the indicator's values for 2008-2017 (see Figure 5) shows its growth to $29.21 \%$ in 2014 , as well as sharp decline after 2014 (to $3.21 \%$ in 2015 and $0.39 \%$ in 2017). In addition, the value of the indicator was in the critical area (up to $15 \%$ ) in 2008-2009, 2011, and 2015-2017.

Return on assets (ROA) is an equally important indicator of assessing the efficient creation and use of the economic entities' financial capacity. For the purposes of the study, the ROA of enterprises was calculated as the ratio of net profit to the average annual value of assets in terms of balance as a percentage (see Figure 6).
Based on the data above, one can conclude that the use of assets of domestic enterprises is unsatisfactory. This is confirmed by losses in 2008, 2009 and in 2014 and 2015 (while in 2014, the total loss amounted to UAH 590.067 billion). Since 2016, there is a positive trend towards increasing the level of return on assets.

The financial capacity of economic entities was generally not used effectively enough. This is proved by the non-compliance of most of the actual values of the indicators with the recommended ones, especially during the military conflict. This is also confirmed by the negative dynamics of the 


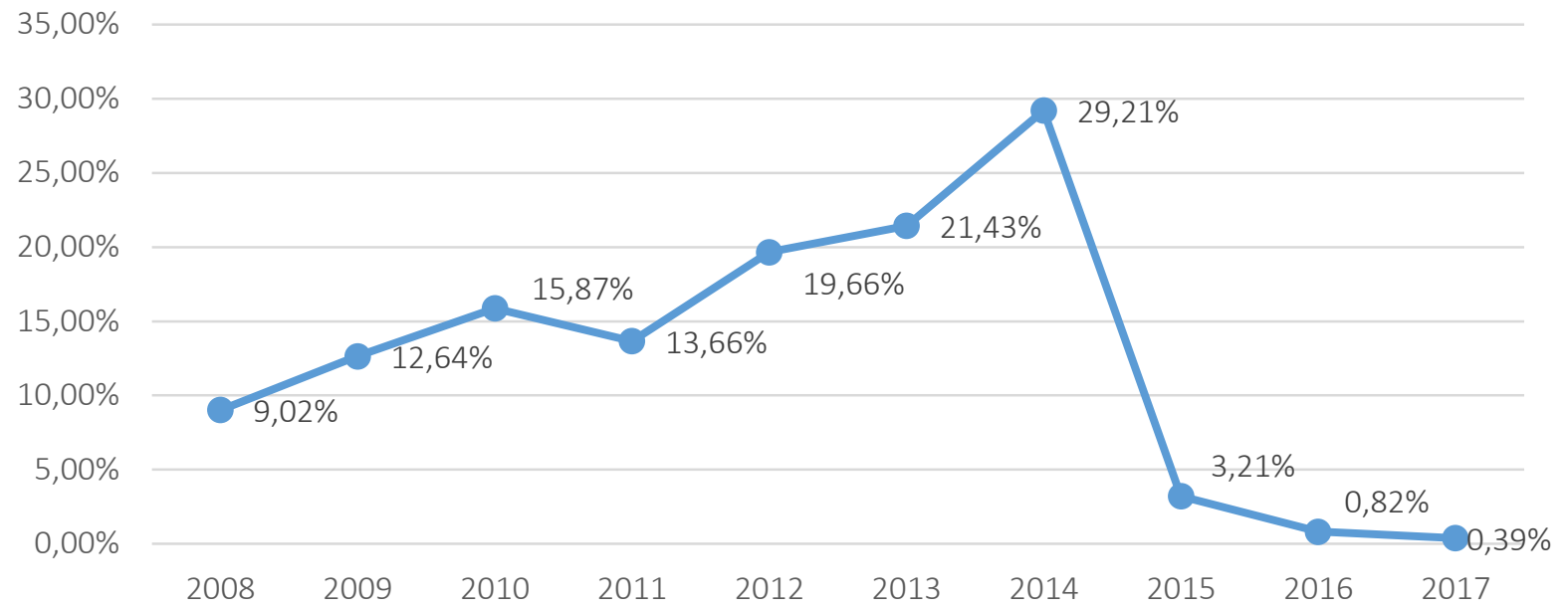

Note: 2017 data are given as of April 30, 2017.

Figure 5. The listing companies capitalization to GDP ratio in $2008-2017, \%$

Source: Developed based on the State Statistics Service of Ukraine data.

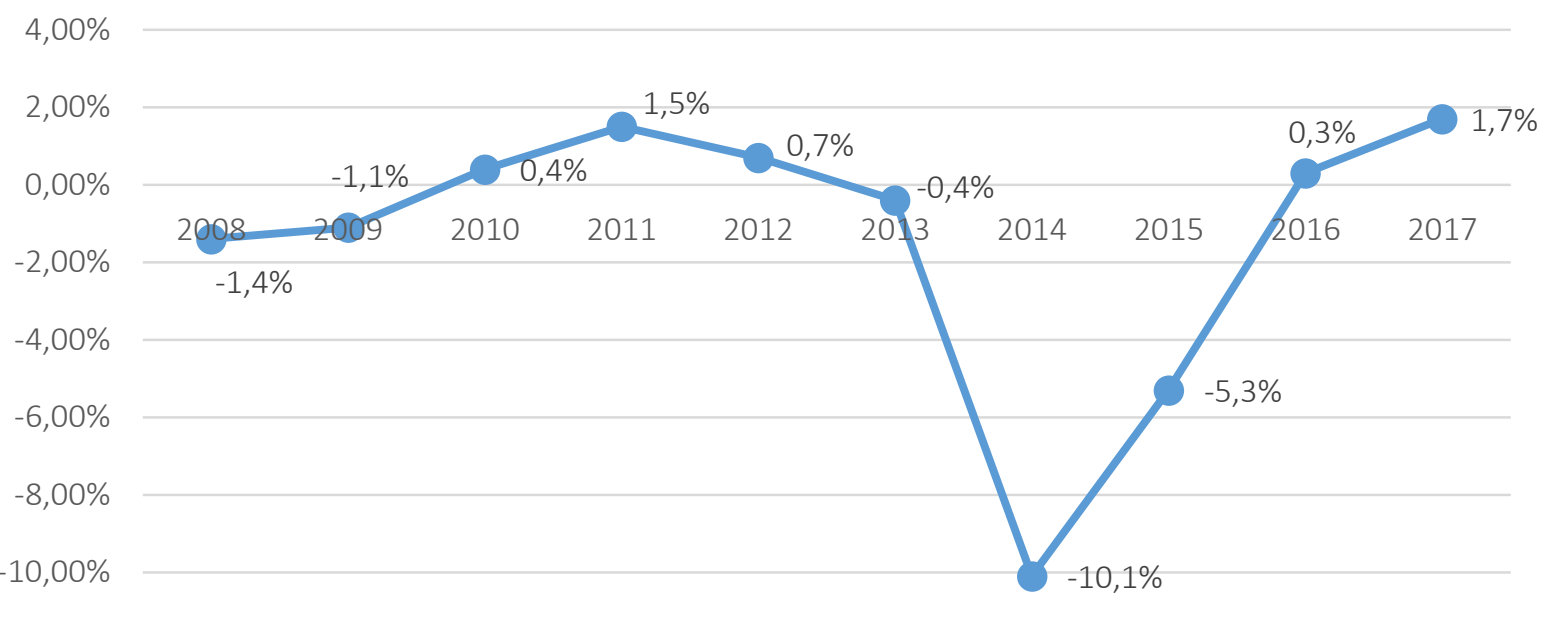

$-12,00 \%$

Figure 6. Return on assets of the Ukrainian enterprises in 2008-2017

overall indicator of the efficient creation and use of economic entities' financial capacity (see Table 8).

Based on the calculated values of indicators for assessing the efficient creation and use of households' financial capacity (see Figure 7), it can be argued that the share of cash income in total household resources during the period analyzed and the share of spending on food and non-alcoholic beverages in total household expenses were relatively stable. The ratio of average old-age pensions to nominal wages showed a negative dynamics. All calculated indicators did not match the recommended value.
Overall, the financial resources and household capacities were not used effectively. This is evidenced by values of the overall indicator of the effectiveness of the relevant component of the state's financial capacity (see Table 9).

An integral indicator of the efficient creation and use of the Ukraine's financial capacity was calculated based on the indicators of the effectiveness of the state's financial capacity components and data on the structure of the state's financial capacity (see Figure 8). 
Table 8. Assessment of indicators of efficient creation and use of the Ukrainian economic entities' financial potential during 2008-2017

Source: Authors' calculations.

\begin{tabular}{|c|c|c|c|c|c|c|c|c|c|c|c|}
\hline \multirow{2}{*}{ No. } & \multirow{2}{*}{ Indicator } & \multicolumn{10}{|c|}{ Years } \\
\hline & & 2008 & 2009 & 2010 & 2011 & 2012 & 2013 & 2014 & 2015 & 2016 & 2017 \\
\hline 1 & $\begin{array}{l}\text { Capitalization level of the listing } \\
\text { companies, \% of GDP }\end{array}$ & 0.33 & 0.33 & 1 & 0 & 1 & 1 & 1 & 0 & 0 & 0 \\
\hline 2 & Credit interest rate & 0 & 0 & 0.33 & 0 & 0 & 0.33 & 0 & 0 & 0.33 & 0.33 \\
\hline 3 & $\begin{array}{l}\text { The non-performing loans to aggregate } \\
\text { gross loans ratio }\end{array}$ & 0.33 & 0 & 0 & 0.33 & 0 & 0.33 & 0 & 0 & 0 & 0 \\
\hline 4 & Return on assets of enterprises, percent & 0 & 0.33 & 1 & 1 & 0.67 & 0 & 0 & 0.33 & 1 & 1 \\
\hline 5 & $\begin{array}{l}\text { Overall indicator of the efficiency of } \\
\text { economic entities' financial capacity }\end{array}$ & 0.165 & 0.165 & 0.583 & 0.333 & 0.418 & 0.415 & 0.250 & 0.083 & 0.333 & 0.333 \\
\hline
\end{tabular}

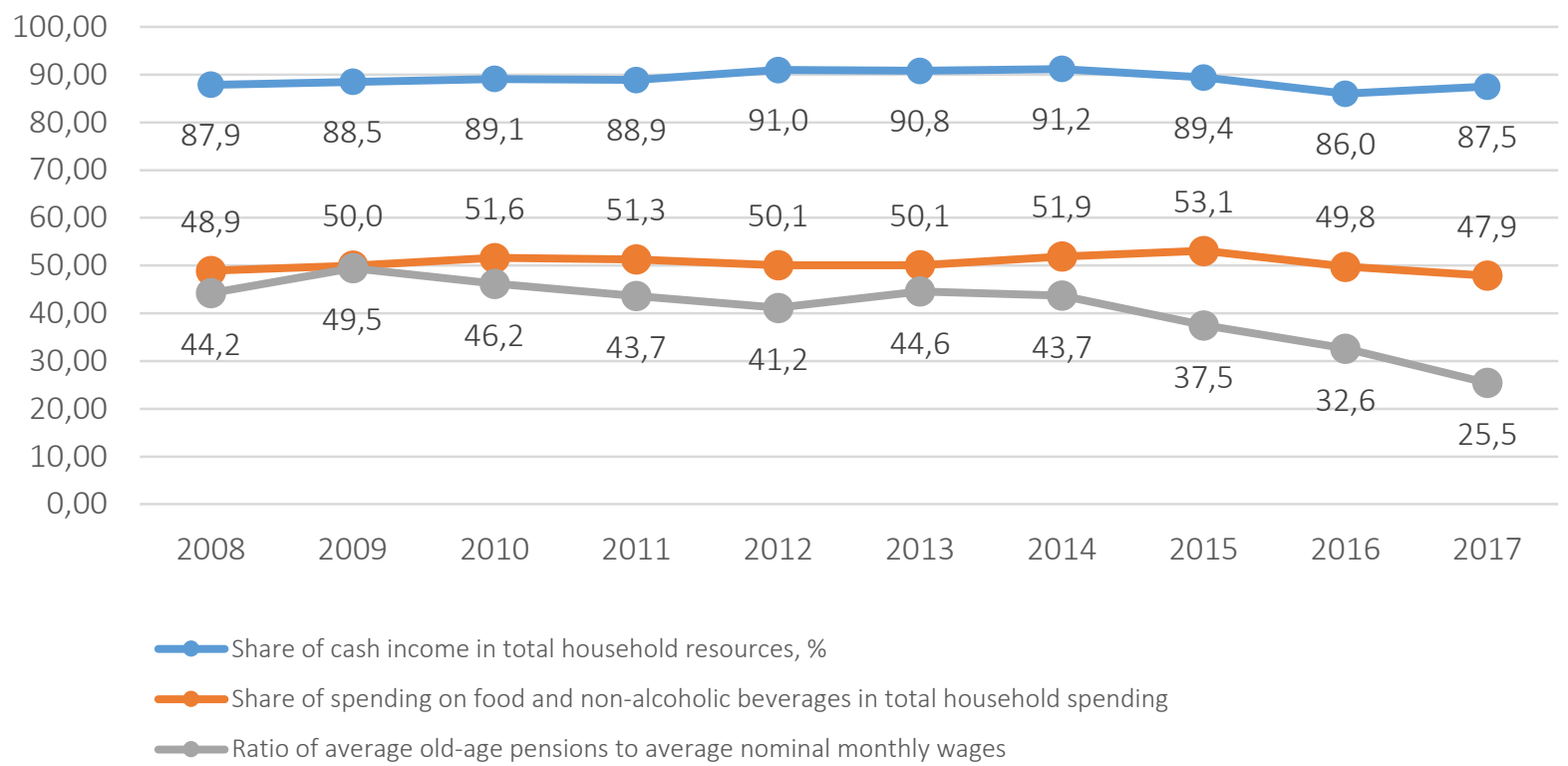

Figure 7. Indicator values of assessing the efficient creation and use of the household financial capacity in 2008-2017

Table 9. Assessment of indicators of efficient creation and use of Ukrainian household financial capacity in 2008-2017

Source: Authors' calculations.

\begin{tabular}{|c|c|c|c|c|c|c|c|c|c|c|c|}
\hline \multirow{2}{*}{ No. } & \multirow{2}{*}{ Indicator } & \multicolumn{10}{|c|}{ Years } \\
\hline & & 2008 & 2009 & 2010 & 2011 & 2012 & 2013 & 2014 & 2015 & 2016 & 2017 \\
\hline 1 & $\begin{array}{l}\text { Share of cash income in total household } \\
\text { resources }\end{array}$ & 0 & 0.33 & 0.33 & 0 & 0.33 & 0 & 0.33 & 0 & 0 & 0.33 \\
\hline 2 & $\begin{array}{l}\text { Ratio of average old-age pensions to } \\
\text { average nominal monthly wages }\end{array}$ & 0.33 & 0.33 & 0 & 0 & 0 & 0.33 & 0 & 0 & 0 & 0 \\
\hline 3 & $\begin{array}{l}\text { Share of spending on food and non- } \\
\text { alcoholic beverages }\end{array}$ & 0.33 & 0 & 0 & 0.33 & 0.33 & 0 & 0 & 0 & 0.33 & 0.33 \\
\hline 4 & $\begin{array}{l}\text { Overall indicator of the efficiency of } \\
\text { household financial capacity }\end{array}$ & 0.22 & 0.22 & 0.11 & 0.11 & 0.22 & 0.11 & 0.11 & 0 & 0.11 & 0.22 \\
\hline
\end{tabular}


0,4

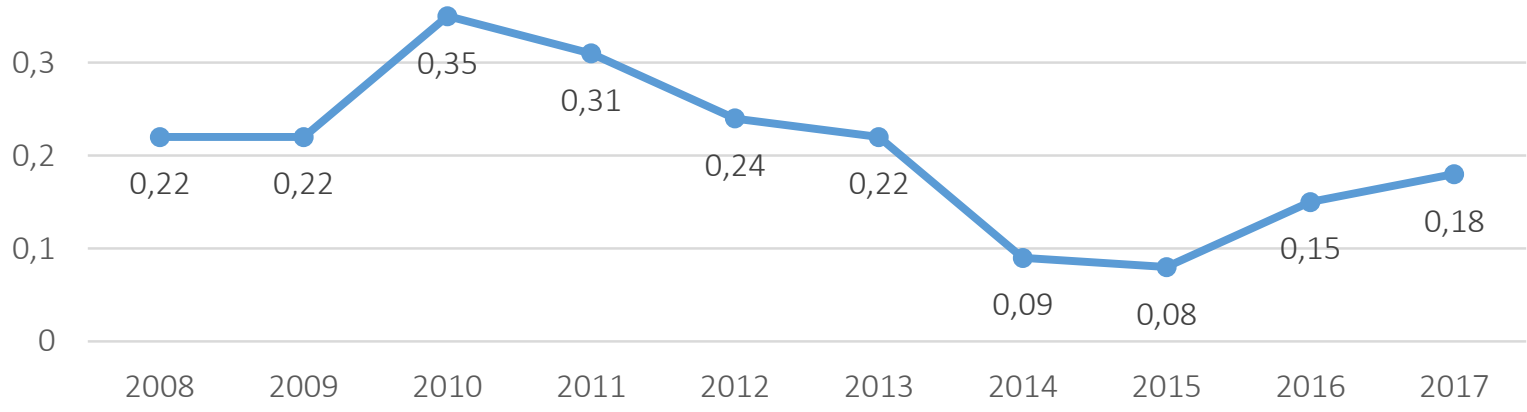

Figure 8. Integral indicator of the efficient creation and use of the Ukraine's financial capacity in 2008-2017

\section{CONCLUSION}

Thus, during 2008-2013, the creation and use of Ukraine's financial capacity was unsatisfactory, and in 2014-2017, it was at a critical level. This is evidenced by the inconsistency of key indicators of the efficient creation and use of the state's financial capacity components and by the recommended values. Based on the indicator values of the efficient creation and use of the state's financial capacity, it is possible to predict its following future trends:

- further decrease in creation and use of authorities' financial capacity. This is due to inconsistency of the state budget spending and its income (the state budget deficit was kept at the level of $3.3 \%$ of GDP), the growth of the volume of government debt and consolidated budget income relative to GDP, insufficient gold and foreign exchange reserves. All this slows economic growth;

- despite the restoring profitability in recent years, the reduction in the efficiency of the creation and use of economic entities financial capacity will be caused by the probably maintaining high credit interest rates, a significant proportion of non-performing loans in total loans and decrease in the domestic stock market capitalization;

- decrease in the average old-age pensions relative to the average monthly nominal wage, high share of spending on food and non-alcoholic beverages in total household expenses, as well as share of cash income in the total household resources will determine the low efficiency of the creation and use of household financial capacity.

The article has proposed a research and methodological approach to a comprehensive assessment of the state's financial potential. It involves using the system of indicators of the efficient creation and use of financial capacity of authorities, business entities, and households, substantiating the scale of their scoring and the procedure for calculating the integral indicator of the efficient creation and use of the state's financial capacity, which made it possible to conclude on the critical level of financial capacity in 2008-2017, the state budget imbalance, the growth of the government debt relative to GDP, the insufficient gold and exchange reserves, increase in the proportion of non-performing loans, low level of the stock market capitalization and the loss-making activity of enterprises in certain periods.

Given the significant influence of the military conflict on the development of the country's financial capacity, it can be argued that further decrease in the fighting and its further cessation will create environment for more efficient creation and use of Ukraine's financial capacity. 


\section{REFERENCES}

1. Adilova, K. A., Akayev, A. M., Zhatkanbayeva, A. E., \& Zhumanova, M. H. (2015). Problems of Financial Security and Financial Stability of the Republic of Kazakhstan. Mediterranean Journal of Social Sciences, 6(6 S2), 426. Retrieved from http://www. mcser.org/journal/index.php/ mjss/article/view/8114

2. Boronos, V. G. (2012). Фінансовий потенціал території у державній фінансовій політиці: методологія і практика управління [Finansovyi potentsial terytorii y derzhavnii finansovii politytsi: metodolohiia i praktyka upravlinnia] (Doctoral dissertation). Retrieved from http://www.essuir.sumdu.edu.ua/ bitstream/123456789/51603/10/ Boronos_Finansovyi_potentsial. pdf

3. EuroStat (n.d.). General government finance statistics (\% of GDP). Retrieved from https:// ec.europa.eu/eurostat/data/database

4. He, Dexu (2016). Financial Security in China: Situation Analysis and System Design (224 p.). Springer.

5. Indus, K. Р. (2016). Управління бінансовим потенціалом України [Upravlinnia finansovym potentsialom Ukrainy] (Doctoral dissertation). Retrieved from http://www.stu. cn.ua/media/files/pdf/dis/ aref_indus.pdf

6. Khalitova, M., Panzabekova, A., \& Nurymova, S. (2017). Analysis and evaluation of the financial security of the national economies of Central Asia. Current science, 112(5). Retrieved from http://204999e1e1be90d6150ad13a17baf6693be23c8c970869869111. r37.cf1.rackcdn.com/ attachments/74c92ff2-c56c30c7-95fc-a4070e364360.pdf

7. Kostyrko, A. G. (2015). Формування і використання фінансового потенціалу сільськогосподарських nідприємств [Formuvannia i vykorystannia finansovoho potentsialu silskohospodarskykh pidpryiemstv] (Doctoral dissertation). Retrieved from http://www. mnau.edu.ua/files/18_02_02/ Thesis-\%D0\%9Aostyrko.pdf

8. Kucher, G. (2014). Фінансовий потенціал економічного розвитку: теоретичний аспект [Finansovyi potentsial ekonomichnoho rozvytku: teoretychnyi aspekt]. Visnyk KNTEU, 4, 92-105. Retrieved from http://www.irbis-nbuv. gov.ua/cgi-bin/irbis_nbuv/ cgiirbis_64.exe?I21DBN=LI $\mathrm{NK} \& \mathrm{P} 21 \mathrm{DBN}=\mathrm{UJRN} \& \mathrm{Z} 21$ $\mathrm{ID}=\& \mathrm{~S} 21 \mathrm{REF}=10 \& \mathrm{~S} 21 \mathrm{CNR}$ $=20 \& S 21 \mathrm{STN}=1 \& \mathrm{~S} 21 \mathrm{FMT}=$ ASP_meta\&C21COM=S\&2 $\mathrm{S} 21 \mathrm{P} 03=\mathrm{FILA}=\& 2$ S21STR=Vknteu $\_2014 \_4$ 9

9. Ministry of Economic Development of Ukraine (2013). Про затвердження Методичних рекомендацій щодо розрахунку рівня економічної безпеки України [Pro zatverdzhennia Metodychnykh rekomendatsii shchodo rozrakhunku rivnia ekonomichnoi bezpeky Ukrainy]. Retrieved from https:// zakon.rada.gov.ua/rada/show/ v1277731-13

10. Ministry of Finance of Ukraine (n.d.). Retrieved from https:// www.minfin.gov.ua/

11. National Commission for State Regulation of Financial Services Markets (n.d.). Retrieved from https://nfp.gov.ua

12. National Securities and Stock Market Commission of Ukraine (n.d.). Retrieved from https:// www.nssmc.gov.ua/

13. Nazarova, T. Y. (2016). Управління фінансовим потенціалом промислового підприємства на засадах синергетичного підходу [Upravlinnia finansovym potentsialom promyslovoho pidpryiemstva na zasadakh synerhetychnoho pidkhodu]. Kharkiv: Ukraine. Retrieved from http://www. irbis-nbuv.gov.ua/cgi-bin/irbis_nbuv/cgiirbis_64.exe?I21
$\mathrm{DBN}=\mathrm{LINK} \& \mathrm{P} 21 \mathrm{DBN}=\mathrm{UJRN}$

$\& Z 21 \mathrm{ID}=\& S 21 \mathrm{REF}=10 \& \mathrm{~S} 21 \mathrm{C}$

$\mathrm{NR}=20 \& \mathrm{~S} 21 \mathrm{STN}=1 \& \mathrm{~S} 21 \mathrm{FMT}$

$=$ ASP_meta $\& \mathrm{C} 21 \mathrm{COM}=\mathrm{S} \& 2$

S21P03 $=$ FILA $=\& 2$

$\mathrm{S} 21 \mathrm{STR}=\mathrm{Vonu}$

econ_2016_21_8_15

14. Polchanov, A. (2018)

Розвиток фінансового

потенціалу держави в системі постконфліктного відновлення [Rozvytok finansovoho potentsialu derzhavy v systemi postkonfliktnoho vidnovlennia] (464 p.). Zhytomyr: ZDTU. Retrieved from https://lib.ztu. edu.ua/?q=ua/publication/polchanov-yu-rozvytok-finansovogopotencialu-derzhavy-v-systemipostkonfliktnogo

15. Portna, O. V. (2015).

Методологічні засади оцінювання сукупного фінансового потенціалу країни [Metodolohichni zasady otsiniuvannia sukupnoho finansovoho potentsialu krainy]. Aktualni problemy ekonomiky, 3, 106112. Retrieved from http:// www.irbis-nbuv.gov.ua/cgi-bin/ irbis_nbuv/cgiirbis_64.exe?I21 $\mathrm{DBN}=\mathrm{LINK} \& \mathrm{P} 21 \mathrm{DBN}=\mathrm{UJRN}$ $\& Z 21 \mathrm{ID}=\& S 21 \mathrm{REF}=10 \& \mathrm{~S} 21 \mathrm{C}$ $\mathrm{NR}=20 \& \mathrm{~S} 21 \mathrm{STN}=1 \& \mathrm{~S} 21 \mathrm{FMT}$ $=$ ASP_meta $\& \mathrm{C} 21 \mathrm{COM}=\mathrm{S} \& 2$ $\mathrm{S} 21 \mathrm{P} 03=\mathrm{FILA}=\& 2$ S21STR=ape_2015_3_14

16. Redo, M., \& Siemiątkowski, P. (2017). External financial security of the state. Torun International Studies, l, 1-161. Retrieved from http://apcz.umk.pl/czasopisma/index.php/TSM/article/ view/TIS.2017.100

17. Semjonova, N. (2016). Financial Security in the Baltic States: Comparison with Selected EU Countries. Economics and Business, 29(1), 90-95. https://doi. org/10.1515/eb-2016-0026

18. Shumska, S. S. (2007). Фінансовий потенціал України: методологія визначення та оцінки [Finansovyi potentsial Ukrainy: metodolohiia vyznachennia ta otsinky]. Finansy Ukrainy, 5, 55-64. Retrieved from http:// 
www.irbis-nbuv.gov.ua/cgi-bin/ irbis_nbuv/cgiirbis_64.exe?I21 $\mathrm{DBN}=\mathrm{LINK} \& \mathrm{P} 21 \mathrm{DBN}=\mathrm{UJRN}$ $\& Z 21 \mathrm{ID}=\&$ S21 REF $=10 \& S 21 \mathrm{C}$ $\mathrm{NR}=20 \& S 21 \mathrm{STN}=1 \&$ S21FMT $=\mathrm{ASP} \_$meta $\& \mathrm{C} 21 \mathrm{COM}=\mathrm{S} \& 2$ S21P03=FILA=\&2 $\mathrm{S} 21 \mathrm{STR}=\mathrm{Fu} \_2007 \_5 \_7$

19. State Statistics Service of Ukraine (n.d.). Retrieved from http://www.ukrstat.gov.ua

20. The Wolrd Bank (n.d.). World Bank Open Data. Retrieved from http://data.worldbank.org/
21. Trusova, N. V. (2016). Формування фінансового потенціалу сільськогосподарських підприємств: теорія, методологія [Formuvannia finansovoho potentsialu silskohospodarskykh pidpryiemstv: teoriia, metodolohiia] (Doctoral dissertation). Retrieved from http:// www.iae.org.ua/images/iae/vchena_rada_02/2016/2016.02.03 trusova_dis.pdf

22. Verkhovna Rada of Ukraine (2010). Бюджетний кодекс україни [Biudzhetnyi kodeks Ukrainy]. Available at http:// zakon2.rada.gov.ua/laws/ show/2456-17

23. Volkovskyi, Ye. I. (2015)

Фінансовий потенціал місцевого самоврядування (на прикладі столиці України - міста Києва) [Finansovyi potentsial mistsevoho samovriaduvannia (na prykladi stolytsi Ukrainy - mista Kyieva)] (Doctoral dissertation). Retrieved from https://kneu.edu. ua/userfiles/d-26.006.04/2016/ Volkovskyi_dis.pdf 